Л. В. Коломієць, д.т.н., О. І. Кисельова, к.пед.н.

Одеська державна академія технічного регулювання та якості, м. Одеса

\title{
МЕТОДИ ЕКСПЕРТНИХ ОЦІНОК У ПРОЦЕСІ ЕКСПЕРТИЗИ НАВЧАЛЬНОГО ПРОЦЕСУ У ВИЩИХ НАВЧАЛЬНИХ ЗАКЛАДАХ
}

У статті представлено етапи, умови, індивідуальні (інтерв'ю, анкетування та бесіда) та колективні (метод комісії, конференції, семінари, дискусії за «круглим столом», метод Дельфі, метод відстороненого оцінювання, метод «мозкового итурму», конференція ідей, метод рангових оцінок) методи проведення експертизи навчального процесу у ВНЗ. На основі отриманих експертних оцінок, щодо визначення оцінки якості навчання студентів у ВНЗ, розроблено і представлено нову концепцію індивідуально-орієнтованого навчання студентів, з метою забезпечення мобільності і свободи вибору студентів, щодо способу і форми отримання знань та їх контрою.

Ключові слова: експертні оцінки, методи проведення експертизи навчального прочесу у ВНЗ, індивідуальні і колективні методи експертних оцінок, індивідуально-орієнтоване навчання.

Актуальність дослідження. В останні роки у системі освіти України набули особливої популярності методи експертних оцінок, засновані на використанні експертної інформації. Вони допомагають встановити ступінь складності та актуальності проблеми, визначити основні цілі і критерії, виявити важливі чинники і взаємозв'язки між ними, вибрати найкращі альтернативи. Більшість 3 цих методів беруть своє походження iз соціологічних та політологічних наук (інтерв'ю, анкетування, опитування), економіки, маркетингу та менеджменту (метод відстороненого оцінювання, метод комісії), але $є$ й міждисциплінарні, які широко застосовуються у психологічних та педагогічних науках (метод Дельфі, мозковий штурм, конференція ідей). Різні методи експертної оцінки широко застосовуються в усіх сферах освіти України - від дошкільної - до вищої та післядипломної освіти.

На думку О. С. Бондар [1] метод експертних оцінок дозволяє аналізувати складні освітні процеси, систему менеджменту освітньої установи, явища або ситуації, які характеризуються в основному якісними, неформалізованими ознаками (що ускладнює їх аналіз та оцінку); використовується при прогнозуванні розвитку системи освіти в іiі взаємозв'язку з соціальним середовищем, для визначення і ранжування за заданим критерієм найбільш істотних факторів, що впливають на функціонування і розвиток освітньої системи. Даний метод забезпечує оцінку альтернативних рішень і вибір кращих варіантів рішення. Особливо актуально впровадження методу експертних оцінок в роботу вищих навчальних закладів, оскільки за допомогою цих методів вирішуються проблеми забезпечення якості вищої освіти та їі оцінки, менеджменту ВНЗ і структурних підрозділів, модернізації та оптимізації навчального процесу ВНЗ.

Мета дослідження: проаналізувати етапи, умови та методи проведення експертизи навчального процесу у ВН3; визначити якість навчання у ВНЗ за допомогою індивідуальних і колективних методів експертних оцінок.

Виклад основного матеріалу дослідження. Різні аспекти проведення експертизи освітнього процесу досліджують В. Г. Афанасьєв, С. В. Гуцикова, Л. Г. Свланов, В. О. Кутузов, І. П. Підласий, С. О. Тарасов, В. С. Черепанов та інші учені. Метод експертних оцінок - це комплекс логічних і математичних процедур, спрямованих на отримання інформації, iï аналіз і узагальнення 3 метою підготовки та прийняття компетентного управлінського рішення [3, с. 12], [7, с. 69-70].

Суть методу полягає в проведенні експертами аналізу проблеми 3 якісною і кількісною оцінкою суджень і формальною обробкою результатів індивідуальних експертних оцінок [8]. Процедура проведення експертної оцінки (експертизи), за О. С. Бондар,складається 3 логічно взаємопов'язаних етапів:

1) Початковий етап: визначення мети i завдань експертизи, постановка проблеми; визначення міри відповідальності, прав і повноважень робочої групи експертів; встановлення термінів проведення експертизи; добір експертів, формування експертних груп (при необхідності визначення їх компетентності) [1].

Для навчально-педагогічної експертизи найчастіше потрібна розробка анкет, опитувальників, тестів, контрольно-діагностичних завдань. Експертна оцінка $\epsilon$ результатом аналітичної діяльності, заснованої на вмінні бачити і вирішувати протиріччя, прогнозувати, передбачати i знаходити нестандартні способи вирішення. Всі 
ці завдання вирішуються на першому етапі.

2) Основний етап експертизи пов'язаний зі збором даних, проведенням дослідницької роботи і експертною оцінкою, аналізом наявного матеріалу. Технологія експертизи, використання сукупності методів і критеріїв оцінки залежать від характеру експертизи, сфери іiї застосування [1].

3) Завершальний етап експертизи - опитування експертів (індивідуальне чи групове; особисте, очне або заочне; усне чи письмове), оформлення документа (звіт, довідка, рецензія тощо), прийняття експертного висновку - основи для компетентного управлінського рішення, яке приймає менеджер [1].

Залежно від галузі застосування експертних методів у навчальному процесі можливе впровадження індивідуальних та колективних експертних оцінок [1], [2], [5], [9]. Для прийняття важливих експертних висновків про перспективи i концепції розвитку системи освіти, впровадження державних стандартів освіти, нових навчальних програм використовується комплекс методів індивідуальних і колективних експертних оцінок. Основні методи експертних оцінок, які застосовуються при експертизі навчального процесу у ВНЗ подано на рис. 1.

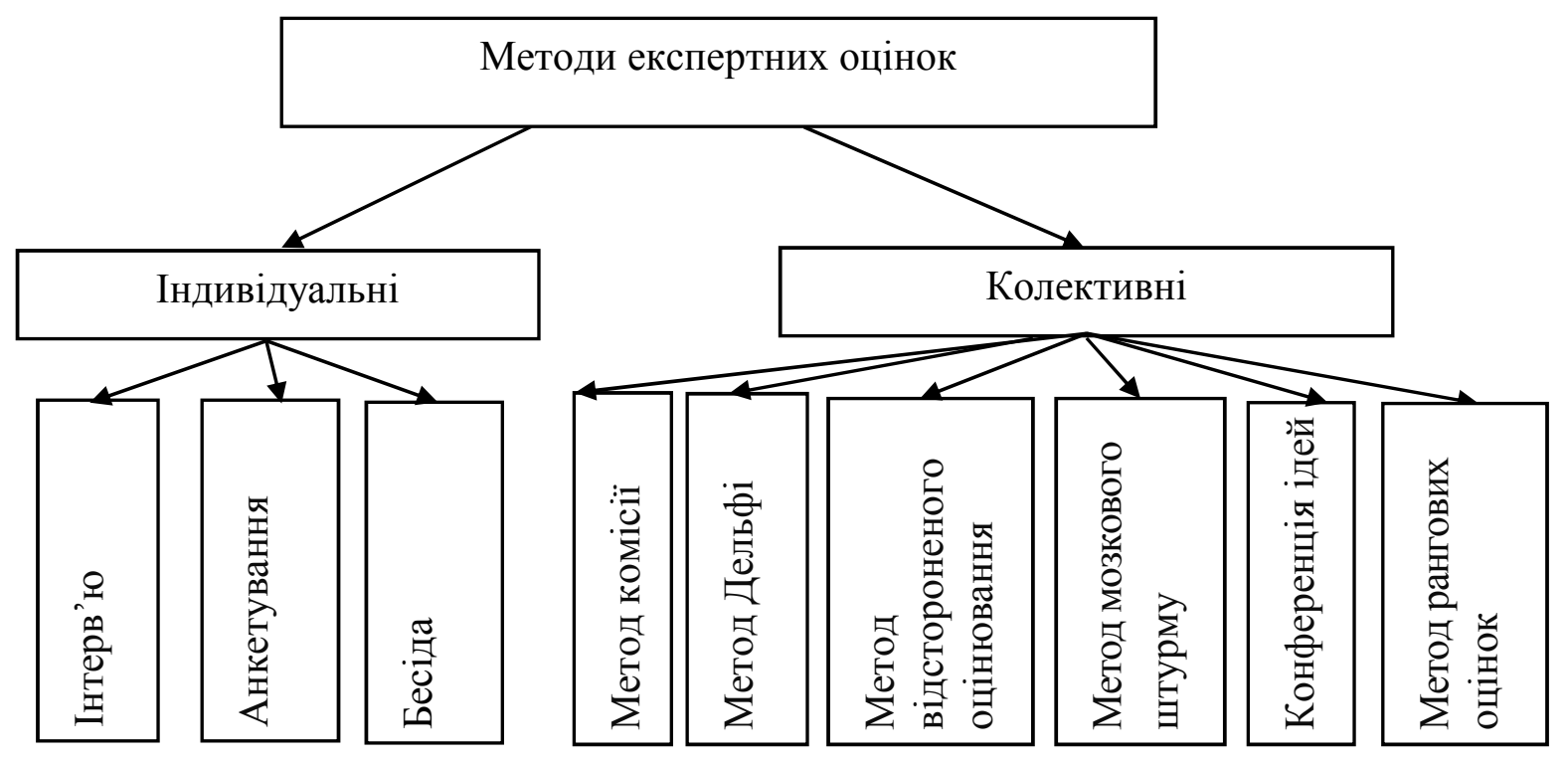

Рисунок 1 - Основні методи експертних оцінок, які застосовуються під час експертизи навчального процесу

Індивідуальні експертні методи - це висновок експерта, сформульований особисто кожним iз них самостійно без врахування думок інших експертів.

До індивідуальних експертних методів належать:

1) інтерв'ю - співбесіда респондента (педагога) 3 експертом, 3 метою з'ясування змісту, форми й методів вирішення питань, які виникли в навчальному процесі, очікуваних результатів навчально-виховної та управлінської діяльності тощо;

2) анкетування - надання респондентом письмових відповідей на запитання анкети, результати анкетування можуть бути спотворені проявами суб' єктивізму опитуваного;

3) бесіда - отримання інформації про досліджуваний об'єкт в логічній формі від досліджуваної особистості, членів досліджуваної групи і від довколишніх людей [6].

Колективні експертні методи - це методи, які забезпечують формування єдиної спільної думки в результаті взаємодії залучених фахівцівекспертів:

1) метод комісії (наради, конференції, семінари, дискусії за «круглим столом»), полягає у вироблені експертами кращого варіанта досягнення поставленої мети з урахуванням усіх висловлених на нараді пропозицій, ідей;

2) метод Дельфі - експертне опитування групи спеціалістів у кілька турів (частіше у $3-4$ тури) для вибору найкращого із рішень (Інтернет-конференції, сліпе рецензування наукових робіт, обмін інформацією 3 використанням спеціально розроблених опитувальників);

3) метод відстороненого оцінювання - вибір оптимального незалежного рішення із числа висловлених експертами на нараді, яка поділена на 
дві частини: висунення ідей та їх критичний аналіз;

4) метод «мозкового штурму» - використовується для знаходження нетрадиційного, оригінального рішення в гранично стислі терміни, шляхом генерування й висунення ідей, $з$ урахуванням критичних зауважень;

5) конференція ідей - подібна до мозкового штурму, але має свої відмінності: більш повільний темп проведення нарад та дозволена коротка конструктивна критика ідей у формі реплік і коментарів, зі стимулюванням поєднання кількох пропозицій, креативності, що сприяє підвищенню якості ідей;

6) метод рангових оцінок - має на меті отримання узагальненого судження експертів, а будь-яку досліджувану інформацію розташовують у порядку зростання або зменшення величини ознаки. Кожній ознаці приписують число, що позначає іiі ранг, отримані результати піддаються математичній обробці. Перевірку узгодженості ранжування визначають обчисленням коефіцієнта рангової кореляції Спірмена або коефіцієнта конкордації [6].

Зазвичай, для проведення експертизи освітнього процесу та освітніх установ, використовуються вже розроблені, апробовані, валідні і об'єктивні методики - результат професійноспрямованих, психолого-педагогічних досліджень. Якщо немає готових методик, експерти розробляють власні за алгоритмом: визначення критеріїв експертної оцінки; визначення номенклатури рівнів (високий, середній, низький або оптимальний, допустимий, недопустимий тощо); відпрацювання набору показників, які в сукупності характеризують рівень розвитку якості, параметра, результату, що оцінюються [2].

Для проведення експертизи освітнього процесу та освітніх установ доцільно використовувати вже розроблені, апробовані, валідні і об'єктивні методики: вони, як правило, є результатом професійно-спрямованих, психологопедагогічних досліджень. За відсутності готових методик, експерти розробляють власні, алгоритм розробки: визначення критеріїв експертної оцінки; визначення номенклатури рівнів (високий, середній, низький або оптимальний, допустимий, недопустимий тощо); відпрацювання набору показників, які в сукупності характеризують рівень розвитку якості, параметра, результату, що оцінюються.

Визначення показників грунтується на тому, що кожен $з$ критеріїв оцінки, наприклад психолого-педагогічні та матеріально-технічні умови навчання студентів, може бути представлений як сукупність підкритеріїв нижчого рівня (ма- теріально-технічна база, що забезпечує професійну спрямованість навчання у ВН3, охорона праці та безпека студентів), а вони, в свою чергу, - у вигляді сукупності підкритеріїв ще більш низького рівня і т.д. Цей процес повторюють до тих пір, поки не з'являється можливість визначити для кожного 3 критеріїв і підкритеріїв один або кілька показників оцінки (наявність обладнання, комп'ютерів, програм для дистанційної освіти, устаткування в аудиторіях, санітарний стан приміщень тощо), які не визначать якість отриманої освіти, але значно впливають на неї. Значення цих підкритеріїв визначають за допомогою вимірювальних методик або експертної оцінки.

Започатковуючи дослідження щодо якості навчання у ВНЗ Одеська державна академія технічного регулювання та якості (ОДАТРЯ), ми провели анкетування студентів і викладачів, розроблене за логікою «постадійного розгортання питання» (Дж. Геллап, Е. І. Дмитрієв) [8]: питання-фільтр, що дозволяє виявити обізнаність опитуваного про проблему; питання, спрямоване на виявлення загального ставлення опитуваного до проблеми (відкрите, яке не передбачає варіантів вибору відповіді); питання для отримання відповіді 3 конкретного аспекту проблеми (закрите, яке передбачає варіанти готових відповідей); питання, що дозволяє виявити причини подій, поглядів, мотивацію суджень (напівзакрите); питання на виявлення стійкості поглядів опитуваного на проблему (в закритій формі).

Застосувавши методи експертних оцінок на практиці і проаналізувавши результати навчального процесу (опитування й анкетування викладачів та студентів, рангові оцінки, семінари, дискусії за «круглим столом» і мозковий штурм), ми отримали наступні результати: необхідно покращити якість навчання, оскільки в середньому у бакалаврів вона складає близько 70\%, а у спеціалістів і магістрів 75\% - 80\%. За результатами експертизи, одним із факторів, що впливає на якість навчання $є$ структура навчального процесу з обов'язковим відвідуванням студентів усіх аудиторних занять та 3 обмеженою можливістю отримати навчальний матеріал дистанційно. Тому, на основі експертних оцінок, ми дійшли висновку, що необхідно розробити нову концепцію навчання студентів, яка б дала студентам більшу мобільність і свободу вибору, щодо способу i форми отримання знань та їх контрою.

Так, виникла ідея індивідуальноорієнтованого навчання студентів (авторський колектив Л. В. Коломієць, С. Л. Волков, О. І. Кисельова), яка в ході обговорень, круглих столів та конференції ідей, втілилась у «Концеп- 
цію індивідуально-орієнтованого навчання». Вона грунтується на Законі України про вищу освіту № 1556-VII від 1 липня 2014 року і впроваджується в освітньо-виховний процес ОДАТРЯ з метою оптимізації навчального процесу i навантаження професорськовикладацького складу ОДАТРЯ.

Основна мета індивідуально-орієнтованого навчання - дати студентам можливість самостійно визначати час відвідування занять і створити більш гнучкий графік навчання (за С.Л. Волковим). Що стає можливим завдяки: навчанню за індивідуальним навчальним планом студента (ІНПС); формуванню розкладу занять за «дисциплінарним» принципом; гнучкому навчальному графіку, можливості для студента самому визначати необхідність і час відвідування занять; мобільності студента, можливості індивідуально виконати і здати тематичні і контрольні завдання; тематичному і підсумковому контролю успішності студентів; моніторингу успішності студентів.

Згідно концепції [4], індивідуальний навчальний план студента (ІНПС) складається на основі плану навчального процесу, який містить блоки навчальних дисциплін (обов'язкових та за вибором навчального закладу і студента). Зміст і обсяг дисциплін визначається вищим навчальним закладом та передбачає профільну спеціалізовану освітньо-професійну або освітньо-наукову програму підготовки здобувачів вищої та післядипломної освіти (ст. 1. Закону України про вищу освіту), із зазначенням навчальних семестрів і анотації дисциплін, які містяться в комплексах дисциплін по кожній спеціальності. ІНПС складається деканатом на кожний наступний рік навчання в кінці поточного року і містить програми всіх навчальних дисциплін, які вивчатиме студент протягом року.

Індивідуально-орієнтоване навчання передбачає також диференційований (індивідуальноорієнтований) підхід до оцінки знань студентів [2], i, відповідно, створення системи диференційованих завдань. Ефективній реалізації дидактичних цілей сприяє відповідна класифікація завдань. Систематизація диференційованих завдань здійснюється: за рівнем складності змісту: виконання студентами роботи, однакової за характером діяльності та різної за наявністю елементів знань, уявлень, понять про об'єкти і явища, зв'язки та залежності між ними; за операційним вмістом: передбачає різну кількість операцій стосовно однакового обсягу змістової інформації; за пізнавальною самостійністю: завдання характеризуються однотипністю 3 операційнозмістового погляду та різноплановістю за мірою допомоги викладача певній групі студентів.

Розв'язання диференційованих завдань означає не зниження загальних вимог для «слабких» i підвищення для «сильних» студентів, а вільний вибір ними варіанта та рівня засвоєння, допомогу «слабким» і створення умов для глибокого засвоєння «сильними». Оцінку здібностей студента проводить викладач під час поточного контролю знань, проте така оцінка не є основним критерієм для обрання поглибленого або базового рівня вивчення дисципліни. Цим критерієм $є$ самооцінка студента, його бажання або небажання поглиблено вивчати дисципліну, брати участь в олімпіадах, конференціях та інших позааудиторних формах роботи.

За результатами застосування на практиці індивідуальних і колективних методів експертних оцінок, можна зробити наступні висновки:

1. Індивідуальні експертні оцінки, отримані шляхом анкетування, інтерв'ю, бесіди, мають наступні переваги: простота організації обстеження, зрозумілість, врахування і використання набутих знань i досвіду кожного експерта. Недоліки: обмеженість знань та інформації експертів з суміжних сфер діяльності.

2. Колективні методи роботи експертів спрямовані на активізацію колективного пошуку рішення проблеми шляхом збору ідей і пропозицій, що виникають в процесі дискусії та обміну досвідом. Це робить колективні методи більш прийнятними та адаптивними до умов освітнього процесу ВН3.

3. Концепція індивідуально-орієнтованого навчання, розроблена на основі отриманих результатів проведеної педагогічної експертизи, 3 метою оцінки якості навчання у ВН3, має на меті підвищення якості, мобільності та успішності навчання студентів.

\section{Список використаних джерел}

1. Бондар О. Оцінювання як функція управління. Електронний ресурс [режим доступу]: http://ru.osvita.ua/school/method/1339/.

2. Гусак П. М. Теорія і технологія диференційованого навчання майбутніх учителів початкових класів. Автореферат дисертації на здобуття наукового ступеня доктора педагогічних наук / спеціальність: 13.00.01 - теорія та історія педагогіки / Петро Миколайович Гусак. - К. : Національний педагогічний університет імені М. П. Драгоманова, 1999.

3. Гуцыкова С. В. Метод экспертных оценок. Теория и практика / С. В. Гуцыкова. - М.: Изд-во «Институт психологии РАН», 2013. - 211 с.

4. Кисельова О. І. Концепція індивідуально- 
орієнтованого навчання студентів / О.І.Кисельова, Л. В. Коломієць, С. Л. Волков // Збірник наукових праць Одеської державної академії технічного регулювання та якості. - Одеса: ОДАТРЯ, 2016. - № 1(8). - С. 13 - 16.

5. Крулехт М. В., Тельнюк И. В. Экспертные оценки в образовании: [Учеб. Пособие для студ. Высш. Пед. Учеб. Заведений] / М. В. Крулехт, И. В. Тельнюк. - М.: Издательский центр «Академия», 2002. - 112 с.

6. Купалова Г. I. Теорія економічного аналізу / Г. І. Купалова [навч. Посібн.] - К.: Знання, 2008. [режим доступу]: http://pidruchniki.com/1584072015160/ekonomika/t eoriya_ekonomichnogo_analizu.

Л. В. Коломиец, д.т.н., О. И. Киселева, к.пед.н.
7. Підласий І. П. Діагностика та експертиза педагогічних проектів [посібник] / I. П. Підласий. - К.: Україна, 1998. - С. 69 - 95.

8. Социология журналистики. Авт-сост. Е. И. Дмитриев. - Минск: БГУ, 2001. - 150 с.

9. Черепанов В. С. Экспертные оценки в педагогических исследованиях: методика педагогической экспертизы / В. С. Черепанов. - М.: Педагогика, 1989. - 152 с.

Надійшла до редакиії 25.10.2016

Рецензент: д. ф.-м. н., проф. Новіков В. М., Одеська державна академія технічного регулювання та якості, м. Одеса.

\section{МЕТОД ЭКСПЕРТНЫХ ОЦЕНОК В ПРОЦЕССЕ ЭКСПЕРТИЗЫ УЧЕБНОГО ПРОЦЕССА В ВЫСШИХ УЧЕБНЫХ ЗАВЕДЕНИЯХ}

В статье представлены этапы, условия, индивидуальные (интервью, анкетирование и беседа) $и$ коллективные (метод комиссии, конференции, семинары, дискуссии за «круглым столом», метод Дельфи, метод отстраненного оченивания, метод «мозгового итурма», конференция идей, метод ранговых оченок) методы проведения экспертизы учебного прочесса в вузе. На основе полученных экспертных оценок, по определению оценки качества обучения студентов в вузе, разработана и представлена новая конщепиия индивидуально-ориентированного обучения студентов, с иелью обеспечения мобильности и свободы выбора студентов, по образу и форме получения знаний и их контроля.

Ключевые слова: экспертные оценки, методы проведения экспертизы учебного процесса в вузе, индивидуальные и коллективные методы экспертных оченок, личностно-ориентированное обучение.

L. V. Kolomiets, DSc, O. I. Kiseleva, PhD

\section{METHOD OF EXPERT EVALUATIONS IN EDUCATION QUALITY SYSTEM EVALUATION IN THE INSTITUTES OF HIGHER EDUCATION}

The article provides stages, conditions, individual (interview, survey and discussion) and collective (commission method, conference, seminars, round-table discussions, Delphi method, method of distant estimation, "brain storm" method, conference of ideas, method of rank estimations) methods of expert examination realization of the educational process in the Institute of Higher Education. On the basis of the received expert estimations about education quality system evaluation in the Institute of Higher Education the following concept was developed and presented: the new individual-oriented educational concept for students with a view to provide mobility and a freedom to choose by students the way and form of receiving their knowledge and the control of it.

Keywords: expert examinations, methods of expert examination realization of the educational process in the Institute of Higher Education, individual and collective methods of expert examinations, individualoriented education. 